\title{
Recent record of Masked Finfoot (Heliopais personata) in Indonesia after 17 years
}

\author{
AGUS NURZA ${ }^{1}$, HUSNURRIZAL ${ }^{2}$, MUHAMMAD IQBAL ${ }^{3,4,4}$ \\ ${ }^{1}$ Aceh Birder, J1. Daud Beureueh No. 55 Kampung Keuramat, Kuta Alam,, Banda Aceh 23126, Indonesia \\ ${ }^{2}$ Laboratory of Reproduction, Faculty of Veterinary Medicine, Universitas Syiah Kuala. Darussalam, Banda Aceh 23111, Aceh, Indonesia \\ ${ }^{3}$ Daemeter Consulting. Jalan Tangkuban Perahu No.6, Taman Kencana, West Java 16151, Indonesia. ”email: kpbsos26@yahoo.com \\ ${ }^{4}$ Commission Member-IUCN Species Survival Commission Bird Red List Authority 2013-2016
}

Manuscript received: 3 October 2016. Revision accepted: 25 June 2017.

\begin{abstract}
Nurza A, Husnurrizal, Iqbal M. 2017. Recent record of Masked Finfoot (Heliopais personata) in Indonesia after 17 years. Bonorowo Wetlands 7: 8-10. Masked Finfoot (Heliopais personata) is currently listed as Endangered based having a tiny and rapidly declining population caused by ongoing loss and degradation of wetlands and especially riverine lowland forest in Asia. Indonesia is one important habitat for this species during the migration period. However, information on Masked Finfoot in Indonesia is very little known. Since October 1992, there has been no further information on the Masked Finfoot in Indonesia. The Recent record of Masked Finfoot in Bangko Lake (Aceh Province, Indonesia) on 31 December 2009 is the only recent record of Masked Finfoot in Indonesia after 17 years break.
\end{abstract}

Keywords: Aceh, endangered, Heliopais personata, Masked Finfoot

\section{INTRODUCTION}

The Masked Finfoot, Heliopais personata (Gray, 1849), is recorded in Bangladesh and northeast India (Assam) through Myanmar and Thailand to Cambodia and Vietnam with uncertain status in Malaysia and Sumatra (Bertram 1996). This species is scarce winter visitor and passage migrant (probably also a resident) in southern Thailand, Peninsular Malaysia, and vagrant in Singapore (Robson 2011). In Indonesia, the bird is a winter visitor to Sumatra and Java (MacKinnon and Phillips 1993). The complete distribution of this species includes South Bangladesh (Sundarbans) and Northeast India (East Arunachal Pradesh, East Assam, South Assam Hills), Myanmar, Laos, Cambodia, and Vietnam; status is uncertain in South Thailand, Malaysia, and Sumatra (Figure 1) (Bertram and Boesman 2017).

Currently, the status is listed as Endangered based on having a tiny and rapidly declining population caused by ongoing loss and degradation of wetlands and especially riverine lowland forest in Asia (BirdLife International 2014). The world population is estimated at fewer than 10,000 birds (Bertram 1996). However, other updated population numbers may now number as low as 1,000 individuals, so is placed in the band 1,000-2,499 individuals; this equates to 667-1,666 mature individuals, rounded here to 600-1,700 mature individuals (BirdLife International 2014).

Since October 1992, there has been no further information on the Masked Finfoot in Indonesia (Birdlife International 2001). To our knowledge, this paper describes the recent record of the Masked Finfoot in Indonesian after a break of 17 years.

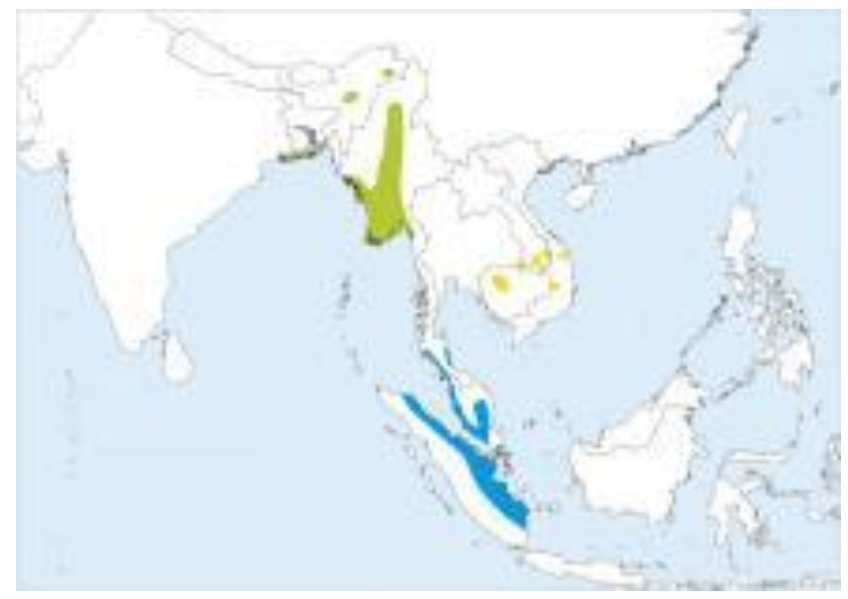

Figure 1. The distribution of Masked Finfoot in South Asia and Southeast Asia (Bertram and Boesman 2017). Note: Green = Extant $($ resident $)$, Yellow $=$ Extant $($ breeding $)$, Blue $=$ Extant (non-breeding)

\section{MATERIALS AND METHODS}

The study site is located in Danau Laut Bangko or Bangko Lake $\left(03^{\circ} 13.2^{\prime \prime} \mathrm{N}, 97^{\circ} 27.6 \mathrm{E}\right)$, Ujung Mangki Village, Bakongan Subdistrict, Aceh Selatan District, Aceh Province, Indonesia. This is a salt lake located at Leuser National Park. The area consists of hilly forests, settlements, and agriculture. The incident of Masked Finfoot in Bangko Lake was recorded on 31 December 2009, during a bird-watching trip. The bird was observed 
and photographed for identification and documentation (Figure 2).

\section{RESULTS AND DISCUSSION}

On 31 December 2009, an incidental observation of an adult Masked Finfoot was taken place. The birds were observed swimming and searching for food for approximately one minute and identified as adults.

Masked Finfoot by its gray hind crown and neck, black face and upper fore neck with a white border, thick yellow bill, body mostly brown above. These are fitted well with characters of Masked Finfoot in various references (MacKinnon and Phillips 1993; Bertram 1996; Robson 2011).

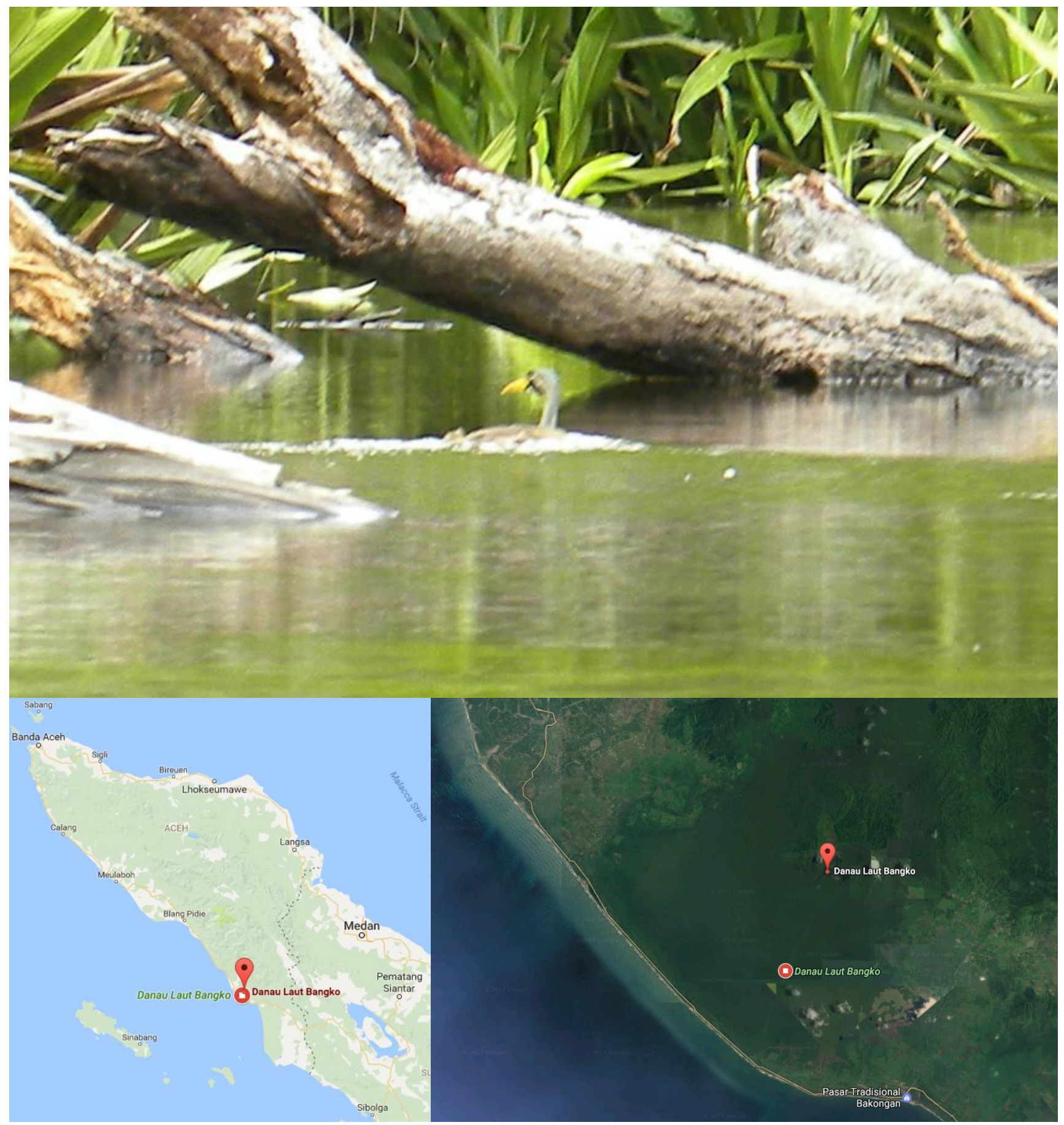

Figure 1. A. Masked Finfoot swims and searching for food in Bangko Lake (Danau Laut Bangko), Aceh Selatan District, Aceh Province, Sumatra, Indonesia on 31 December 2009 (Photo: Agus Nurza). B. Location of Bangko Lake in Sumatra. 
This recent record of Masked Finfoot in Bangko Lake (Danau Laut Bangko, Aceh Selatan) on 31 December 2009 is unexpected. There are previous few records of Masked Finfoot in Sumatra, including Aceh (Alas river, Ketambe) in 1974 and 1978 (Marle and Voous 1988). The latest record of Masked Finfoot in Indonesia is in October 1992, when one adult and one immature were seen at different localities in a dense mangrove in Riau (Burn and Brickle 1992; Birdlife International 2001). The record of Masked Finfoot in Bangko Lake is the only recent record of Masked Finfoot in Indonesia after 17 years break.

We hope that researchers and birdwatchers in Indonesia will pay more attention to Masked Finfoot to determine the status and support its conservation in Indonesia. It looks like the bird is a possible regular visitor in a small number in Sumatra, but the limited number of birdwatchers could have it overlooked in the past.

To conclude, the recent record of Endangered Masked Finfoot in Sumatra after 17 years break is unexpected. The status in Sumatra or Indonesia is uncertain, but it is presumed Indonesia is an essential wintering habitat for this species during the migration period. A further survey is needed to determine the status of this species in Indonesia.

\section{ACKNOWLEDGEMENTS}

We thank Dr. Bas van Balen who provided us with recent information on Masked Finfoot in Indonesia. We would like to thank our friends in Cicem Nangroe and local people in Bangko Lake for their support during our fieldwork. Thanks to anonymous reviewers for their constructive discussion and advice.

\section{REFERENCES}

Bertram BCR, Boesman P. 2017. Masked Finfoot (Heliopais personatus) In: del Hoyo J, Elliott A, Sargatal J, Christie DA, de Juana E (eds) Handbook of the Birds of the World Alive. Lynx Edicions, Barcelona. http://www.hbw.com/node/53706

Bertram BCR. 1996. Family Heliornithidae (Finfoots). In: del Hoyo AE, Sargatal J (eds) Handbook of the Birds of the World, 3. (Jacamars to Woodpeckers). Lynx Edicions, Barcelona.

BirdLife International. 2001. Threatened Birds of Asia: The Birdlife International Red Data Book. Birdlife International, Cambridge.

BirdLife International. 2014. Species factsheet: Heliopais personata. http://www.birdlife.org.

MacKinnon J, Phillips K. 1993 A Field Guide to The Birds of Borneo, Sumatra, Java, and Bali. Oxford University Press, Oxford, UK

Marle JG, Voous KH. 1988. The Birds of Sumatra: An Annotated Checklist. BOU Checklist No. 10, UK.

Robson C. 2011. Birds of Southeast Asia. New Holland Publishers, London, UK. 